\title{
PAPOLA Gene
}

National Cancer Institute

\section{Source}

National Cancer Institute. PAPOLA Gene. NCI Thesaurus. Code C38946.

This gene plays a role in the maturation of mRNA. 